\title{
Impact of perioperative blood transfusion on clinical outcomes in patients with colorectal liver metastasis after hepatectomy: a meta-analysis
}

\author{
Xinghua Lyu' ${ }^{1}$, Wenhui Qiao', Debang $\mathrm{Li}^{1}$ and Yufang Leng ${ }^{1}$ \\ ${ }^{1}$ Department of Anaesthesiology, The First Hospital of Lanzhou University, Lanzhou, China \\ Correspondence to: Yufang Leng, email: yufangleng@sina.cn \\ Keywords: colorectal, liver, oncology, outcomes \\ Received: November 07, 2016 Accepted: March 09, $2017 \quad$ Published: March 31, 2017 \\ Copyright: Lyu et al. This is an open-access article distributed under the terms of the Creative Commons Attribution License 3.0 (CC BY 3.0), \\ which permits unrestricted use, distribution, and reproduction in any medium, provided the original author and source are credited.
}

\section{ABSTRACT}

BACKGROUND: Perioperative blood transfusion may be associated with negative clinical outcomes in oncological surgery. A meta-analysis of published studies was conducted to evaluate the impact of blood transfusion on short- and long-term outcomes following liver resection of colorectal liver metastasis (CLM).

MATERIALS AND METHODS: A systematic search was performed to identify relevant articles. Data were pooled for meta-analysis using Review Manager version 5.3.

RESULTS: Twenty-five observational studies containing 10621 patients were subjected to the analysis. Compared with non-transfused patients, transfused patients experienced higher overall morbidity (odds ratio [OR], 1.98; 95\% confidence intervals $[\mathrm{CI}]=1.49-2.33)$, more major complications $(O R, 2.12 ; 95 \% \mathrm{CI}=1.26-3.58)$, higher mortality (OR, 4.13; 95\% CI =1.96-8.72), and longer length of hospital stay (weighted mean difference, $4.43 ; 95 \% \mathrm{CI}=1.15-7.69)$. Transfusion was associated with reduced overall survival (risk ratio $[R R], 1.24,95 \% \mathrm{CI}=1.11-1.38$ ) and disease-free survival $(R R, 1.38,95 \% \mathrm{CI}=1.23-1.56)$.

CONCLUSION: Perioperative blood transfusion has a detrimental impact on the clinical outcomes of patients undergoing CLM resection.

\section{INTRODUCTION}

Colorectal cancer is the third most common malignancy worldwide with approximately $50 \%$ patients developing liver metastasis during the course of disease. Hepatic resection represents potentially curative treatment for colorectal liver metastasis (CLM) and offers an opportunity of long-term survival benefit, with 5-yeart overall survival (OS) rate of $37-58 \%$ [1]. Although advances in surgical techniques and perioperative care have decreased the morbidity and mortality remarkably in high-volume centers, a considerable proportion of patients have to receive perioperative blood transfusion (PBT) [2-4]. Transfusion-related immune modulation may compromise the clinical outcomes in oncological surgery. However, data for evaluating the impact of PBT on shortand long-term outcomes following CLM resection are limited due to small sample sizes in most reported studies
[2-10]. In this study, we made a meta-analysis on the presently existing data in the literature to assess this issue.

\section{RESULTS}

Selection of studies

The initial search yielded 3856 articles, of which 25 published between 1988 and 2017 were finally qualified for the inclusion criteria in the meta-analysis [2-9, 11-26]. The process of study selection is shown in Figure 1. Study characteristics are shown in Table 1. Two articles from the same institution were included [5, 9], the former mainly assessing the impact of transfusion on perioperative morbidity and mortality, and the latter mainly assessing the impact of transfusion on long-term survival. All identified 
studies were observational design studies involving a total of 10621 patients. Seven studies were from USA $[5,7,9,16,21,22,24]$, four from Italy $[4,8,12,13]$, three from Japan $[3,14,18]$, two from UK $[11,25]$, two from Germany [20, 23], one from Sweden [2], one from France [6], one from Spain [10], one from Brazil [15], one from China [17], one from Canada [19], and one from the Netherlands [26]. The blood product transfusion rate was highly variable across studies ranging from $13.5 \%$ to $91.5 \%$. The sample size of each study varied from 65 to 1351 patients.

\section{Meta-analysis}

Table 2 shows the results for the outcomes.

Four studies compared the characteristics of transfused patients versus those nontransfused patients [16, 19-21]. Pooled analysis showed that transfusion was associated with female gender $(P<0.001)$, higher prevalent preoperative anemia $(P<0.001)$, more extended or major hepatectomy $(P<0.001)$, increased estimated blood loss $(P<0.001)$, and longer duration of surgery ( $P$ $<0.001)$.

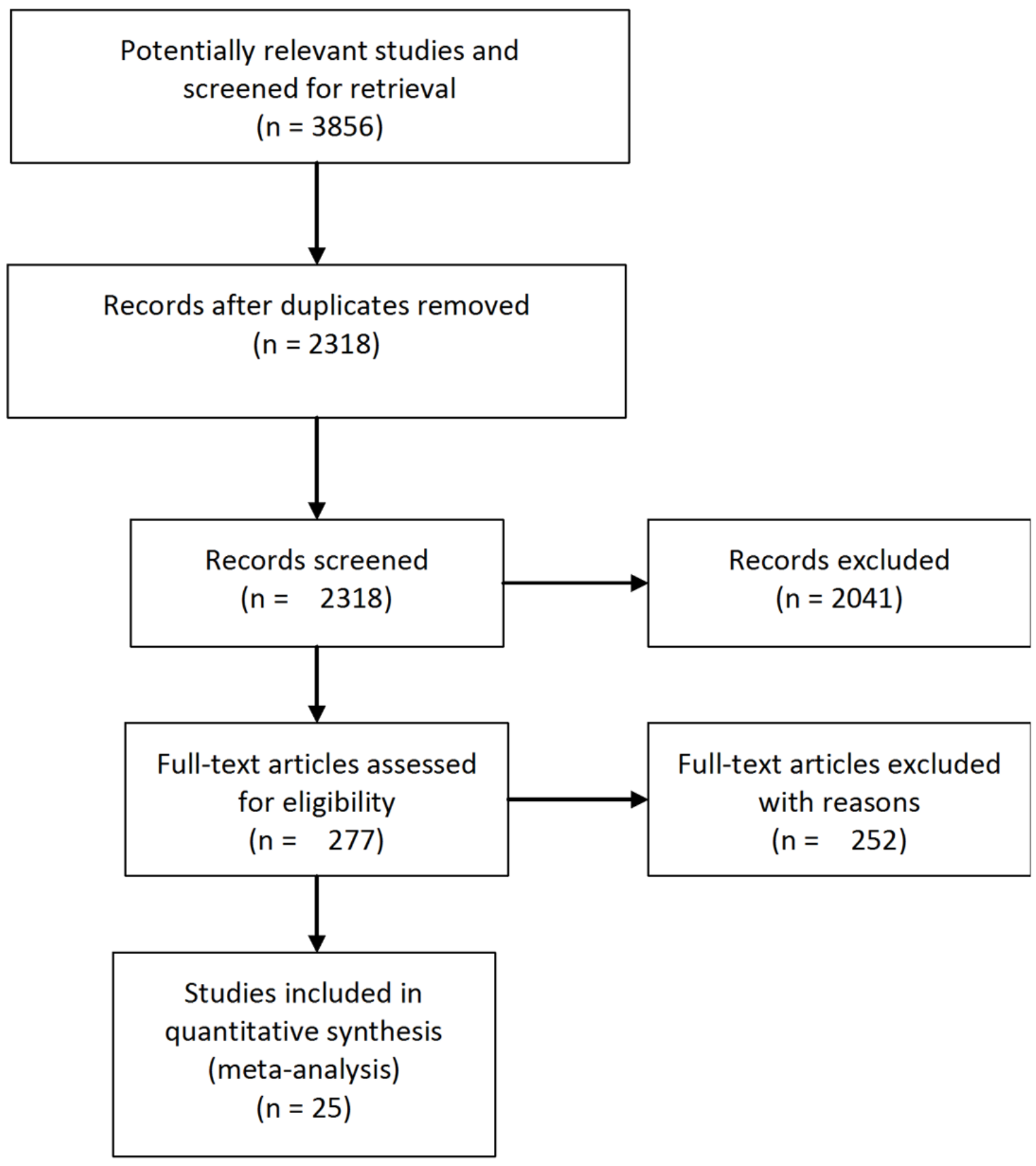

Figure 1: Flowchart of study selection. 
Table 1: Clinical background of studies included in the meta-analysis.

\begin{tabular}{|c|c|c|c|c|c|c|c|c|c|c|c|c|}
\hline Reference & Year & \begin{tabular}{|l|}
$\begin{array}{l}\text { No. of } \\
\text { patients }\end{array}$ \\
\end{tabular} & \begin{tabular}{|l|} 
PT \\
$(\%)$
\end{tabular} & $\mathbf{M} / \mathbf{F}$ & \begin{tabular}{|l|} 
Age, \\
years
\end{tabular} & TS,cm & \begin{tabular}{|l|} 
No. of \\
Tumor
\end{tabular} & \begin{tabular}{|l|}
$\begin{array}{l}\text { Morbidity } \\
\text { (\%) }\end{array}$ \\
\end{tabular} & \begin{tabular}{|l|}
$\begin{array}{l}\text { Mortality } \\
(\%)\end{array}$ \\
\end{tabular} & \begin{tabular}{|l|}
$\begin{array}{l}5 \mathrm{y}-\mathrm{OS} \\
(\%)\end{array}$ \\
\end{tabular} & \begin{tabular}{|l|}
$5 y-D F S$ \\
$(\%)$
\end{tabular} & \begin{tabular}{|l|} 
Study \\
quality
\end{tabular} \\
\hline Ohlsson [2] & 1998 & 111 & 91.5 & $60 / 51$ & $\geq 65, n=75$ & $\geq 5, \mathrm{n}=54$ & $\geq 2, n=50$ & 17.1 & 3.6 & 25 & 19 & 6 \\
\hline Ambiru [3] & 1999 & 168 & 77.4 & $104 / 64$ & $62(21-80)$ & $\geq 5, n=56$ & $\geq 4, n=38$ & 29.7 & 3.5 & 26 & NA & 6 \\
\hline Ercolani [4] & 2002 & 245 & 43.0 & $144 / 102$ & $>60, \mathrm{n}=115$ & NA & $\geq 3, \mathrm{n}=41$ & 18.7 & 0.8 & 34 & NA & 7 \\
\hline Kooby [5] & 2003 & 1351 & 54 & $772 / 579$ & $\mathrm{NA}$ & NA & NA & 40 & 3.7 & 36 & NA & 8 \\
\hline Laurent [6] & 2003 & 311 & 15.7 & $209 / 102$ & $63(31-86)$ & $\geq 5, \mathrm{n}=142$ & $>3, n=42$ & 29.9 & 2.8 & 36 & 24 & 9 \\
\hline Zakaria [7] & 2007 & 662 & 55.2 & $404 / 258$ & $60 \pm 11$ & NA & NA & NA & 2.8 & 42 & NA & 7 \\
\hline Arru [8] & 2008 & 297 & 53.2 & $171 / 126$ & $\geq 65, \mathrm{n}=120$ & $>5, \mathrm{n}=98$ & $\geq 2, \mathrm{n}=117$ & 17.0 & NA & 27.5 & NA & 9 \\
\hline Ito [9] & 2008 & 1067 & 44.6 & $596 / 471$ & $61 \pm 0.37$ & $5.0 \pm 3.7$ & $3.4 \pm 0.05$ & 42.2 & Excluded & 41 & 25 & 7 \\
\hline Hernández [10] & 2009 & 210 & 24.2 & $140 / 70$ & $61 \pm 12$ & $\geq 5, \mathrm{n}=80$ & $\geq 3, n=67$ & 42.9 & 1.4 & 53.8 & 23 & 7 \\
\hline Farid [13] & 2010 & 705 & 21.1 & $442 / 263$ & $46(23-91)$ & $4(0.1-23)$ & $3(1-21)$ & 7.9 & 3.5 & 34 & 22 & 8 \\
\hline Giuliante [14] & 2010 & 543 & 23 & $309 / 234$ & $62(24-83)$ & $4.5 \pm 3.0$ & $2.0(1-14)$ & 18.5 & 1.3 & 36.5 & 25.7 & 7 \\
\hline Gruttadauria [15] & 2011 & 127 & 40.2 & $72 / 55$ & $63(55-69)$ & $\mathrm{NA}$ & NA & 47.2 & NA & $\mathrm{NA}$ & $\mathrm{NA}$ & 8 \\
\hline Kaibori [16] & 2012 & 119 & 37.8 & $70 / 49$ & $>64, n=62$ & $>3.5, n=59$ & $\geq 3, n=38$ & 22.6 & 0 & 38.7 & 33.7 & 8 \\
\hline Ribeiro [17] & 2012 & 170 & 31.7 & $91 / 79$ & $59(23-80)$ & $>5, n=72$ & $\geq 3, \mathrm{n}=64$ & & 2.9 & 64.9 & 39.1 & 7 \\
\hline Cannon [18] & 2013 & 239 & 26.8 & NA & 61.4 & 4.6 & - & 47.3 & 2.5 & 32.7 & 18.1 & 8 \\
\hline Jiang [19] & 2013 & 139 & 25.8 & $91 / 48$ & $58(25-82)$ & $2.5(0.3-11.5)$ & $\geq 2, n=66$ & 12 & 0 & 53 & 48 & 9 \\
\hline Shiba [20] & 2013 & 65 & 41.5 & $45 / 20$ & $64.1 \pm 10.0$ & NA & $1.8 \pm 2.1$ & 29.2 & NA & 46.7 & NA & 7 \\
\hline Hallet [21] & 2015 & 483 & 27.5 & 299/184 & NA & NA & NA & NA & 4.8 & 56.8 & 27.0 & 9 \\
\hline Schiergens [22] & 2015 & 292 & 36.3 & $193 / 99$ & $65(21-86)$ & $>5, n=52$ & $\geq 3, n=43$ & 40 & 5 & 49 & 49 & 9 \\
\hline Postlewait [23] & 2016 & 456 & 30.7 & $252 / 204$ & $58.6 \pm 12.0$ & $4.6 \pm 3.2$ & $1.9 \pm 1.2$ & 21.2 & 1.3 & 36.5 & NA & 7 \\
\hline Zimmitti [24] & 2016 & 510 & 17.6 & $309 / 201$ & $57(23-87)$ & $2.3(0.3-11.5)$ & $1(0-80)$ & 40.4 & Excluded & 56.6 & 31.6 & 7 \\
\hline Kulik [25] & 2016 & 983 & 52.2 & $605 / 378$ & $\geq 70, \mathrm{n}=235$ & $>5, \mathrm{n}=377$ & $\geq 2, n=501$ & 17.7 & 1.2 & $\mathrm{NA}$ & $\mathrm{NA}$ & 6 \\
\hline Margonis [26] & 2016 & 433 & 13.5 & $255 / 178$ & $54(44-64)$ & $2.8(1.7-4.5)$ & $5(2-7)$ & NA & NA & 49.3 & NA & 6 \\
\hline Bell [27] & 2017 & 727 & 13.5 & $466 / 261$ & $64(25-88)$ & $>5, n=270$ & $>3, n=281$ & 26 & 4.5 & NA & NA & 6 \\
\hline Olthof [28] & 2017 & 208 & NA & $136 / 72$ & $64(56-71)$ & $3.1(2-5.1)$ & $2(1-3)$ & 36 & 1 & 59 & 29 & 8 \\
\hline
\end{tabular}

Abbreviations: $\mathrm{PT}=$ perioperative transfusion, $\mathrm{M}=$ male, $\mathrm{F}=$ female, $\mathrm{TS}=$ tumor size, $\mathrm{NA}=$ not available; $\mathrm{OS}=\mathrm{overall}$ survival; $\mathrm{DFS}=$ disease-free survival

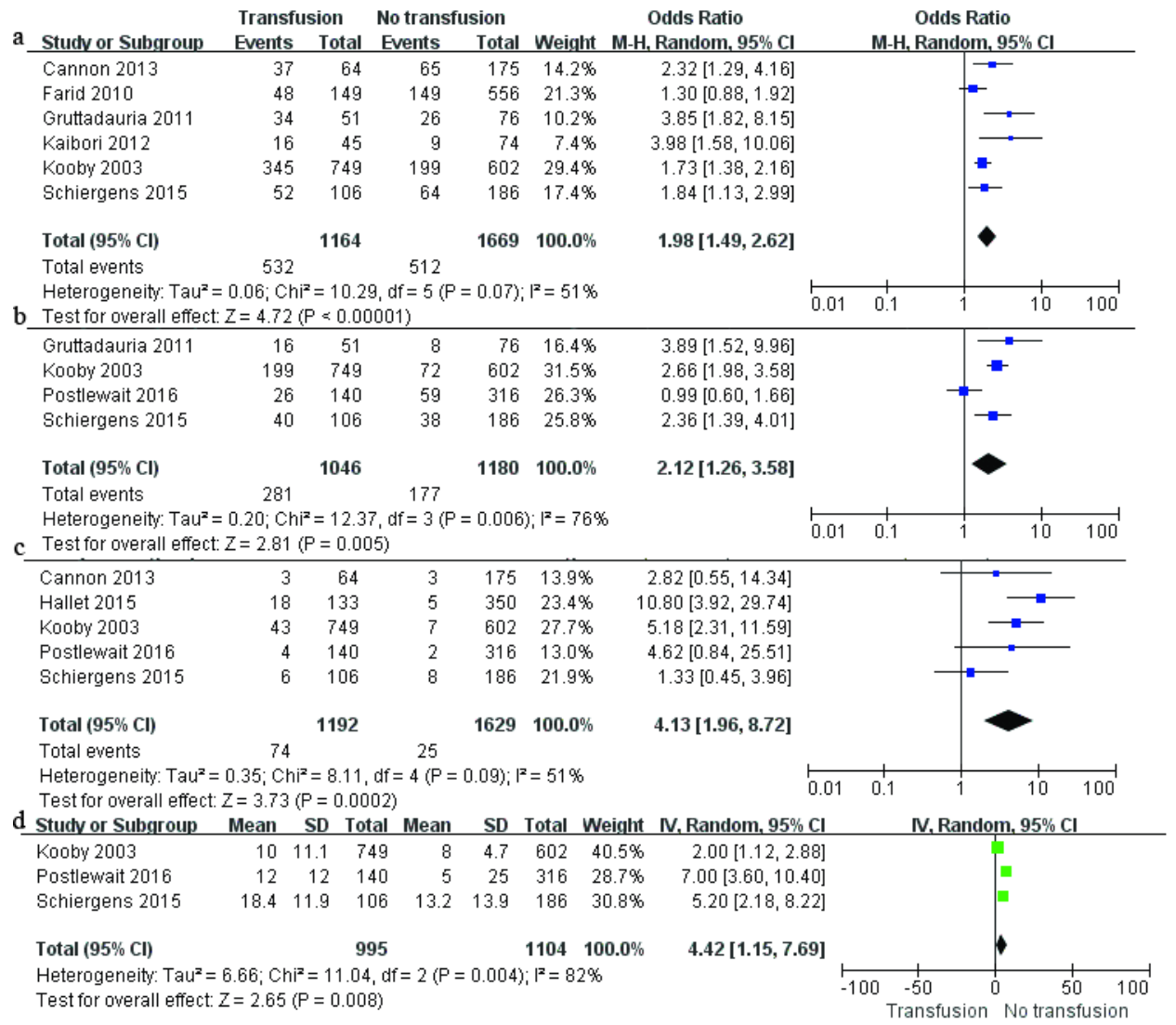

Figure 2: Results of the meta-analysis on perioperative outcomes. a. overall morbidity; b. major complications; c. mortality; and d. lengths of hospital stay. 
Table 2: Meta-analysis of short and long-term outcomes

\begin{tabular}{|c|c|c|c|c|c|c|}
\hline Outcome of interest & Studies & Participants & OR/WMD & $95 \% \mathrm{CI}$ & $P$-value & $I^{2}(\%)$ \\
\hline \multicolumn{7}{|l|}{ Clinicopathologic features } \\
\hline Male gender & 3 & 1231 & 0.58 & $0.46,0.75$ & $<0.001$ & 0 \\
\hline Age & 4 & 1470 & 0.10 & $-1.28,1.47$ & 0.10 & 40 \\
\hline Body mass index & 2 & 695 & -0.26 & $-1.26,0.74$ & 0.62 & 0 \\
\hline Preoperative anemiaa & 2 & 775 & 2.51 & $1.83,3.45$ & $<0.001$ & 0 \\
\hline $\mathrm{ASA}>2$ & 2 & 748 & 1.15 & $0.59,2.24$ & 0.69 & 76 \\
\hline Extended or major resection & 4 & 1470 & 1.64 & $1.28,2.09$ & $<0.001$ & 0 \\
\hline Duration of surgery (min) & 2 & 775 & 55.64 & $42.14,69.14$ & $<0.001$ & 0 \\
\hline Blood loss (mL) & 4 & 1470 & 726.88 & $376,91,1076.84$ & $<0.001$ & 93 \\
\hline Tumor size $(\mathrm{cm})$ & 2 & 695 & 0.95 & $-0.13,2.03$ & 0.09 & 78 \\
\hline Tumor number & 2 & 695 & -0.03 & $-0.49,0.44$ & 0.90 & 59 \\
\hline Negative surgical margin & 4 & 1470 & 1.03 & $0.70,1.51$ & 0.89 & 0 \\
\hline \multicolumn{7}{|l|}{ Postoperative outcomes } \\
\hline Overall morbidity & 6 & 2833 & 1.98 & $1.49,2.33$ & $<0.001$ & 51 \\
\hline Major complication & 4 & 2226 & 2.12 & $1.26,3.58$ & 0.005 & 76 \\
\hline Mortality & 5 & 2821 & 4.13 & $1.96,8.72$ & $<0.001$ & 51 \\
\hline Length of stay (day) & 3 & 2099 & 4.42 & $1.15,7.69$ & 0.008 & 82 \\
\hline \multicolumn{7}{|l|}{ Long-term outcomes } \\
\hline Overall survival & 21 & 8732 & 1.24 & $1.11,1.38$ & 0.0002 & 71 \\
\hline Disease-free survival & 11 & 5018 & 1.38 & $1.23,1.56$ & $<0.001$ & 17 \\
\hline
\end{tabular}

Abbreviations: $\mathrm{OR}=$ odds ratio, $\mathrm{WMD}=$ weighted mean difference, $\mathrm{CI}=$ confidence interval,

$\mathrm{ASA}=$ American Society of Anesthesiologists

The impact of PBT on perioperative outcomes was evaluated in 6 studies $[5,11,13,14,16,20]$. As shown in Figure 2, compared with nontransfused patients, transfused patients experienced higher overall morbidity $(P<0.001)$, more major complication (Clavien-Dindo class 3-5 [27]) $(P=0.005)$, higher mortality $(P<0.001)$, and longer lengths of hospital stay $(P<0.001)$.

The impact of PBT on OS and disease-free survival (DFS) was evaluated in 21 [2-9, 11, 12, 15-19, 21-26] and $11[6,8,11,12,15-17,19,20,22]$ studies, respectively.
Risk Ratio

\begin{tabular}{|c|c|c|c|c|}
\hline Studv or Subgroup & log[Risk Ratio] & SE & Weight & IV. Random, 95\% Cl \\
\hline Ambiru1999 & 0.1713 & 0.36 & $2.0 \%$ & $1.19[0.59,2.40]$ \\
\hline Arru 2008 & -0.2231 & 0.1468 & $5.8 \%$ & $0.80[0.60,1.07]$ \\
\hline Bell 2017 & 0.1989 & 0.1276 & $6.5 \%$ & $1.22[0.95,1.57]$ \\
\hline Cannon 2013 & 0.1154 & 0.2369 & $3.6 \%$ & $1.12[0.71,1.79]$ \\
\hline Ercolani 2002 & 0.1372 & 0.1788 & $4.9 \%$ & $1.15[0.81,1.63]$ \\
\hline Farid 2010 & 0.0971 & 0.1513 & $5.7 \%$ & $1.10[0.82,1.48]$ \\
\hline Giuliante 2010 & 0.4253 & 0.1637 & $5.3 \%$ & $1.53[1.11,2.11]$ \\
\hline Hallet 2015 & 0.8065 & 0.1717 & $5.1 \%$ & $2.24[1.60,3.14]$ \\
\hline Hernández 2009 & -0.1421 & 0.1441 & $5.9 \%$ & $0.87[0.65,1.15]$ \\
\hline Ito 2008 & 0.4824 & 0.4752 & $1.3 \%$ & $1.62[0.64,4.11]$ \\
\hline Jiang 2013 & 0.3365 & 0.4323 & $1.5 \%$ & $1.40[0.60,3.27]$ \\
\hline Kulik 2016 & 0.3365 & 0.0785 & $8.1 \%$ & $1.40[1.20,1.63]$ \\
\hline Laurent 2003 & 0.1256 & 0.2204 & $3.9 \%$ & $1.13[0.74,1.75]$ \\
\hline Margonis 2016 & 0.1823 & 0.2005 & $4.4 \%$ & $1.20[0.81,1.78]$ \\
\hline Ohlsson 1998 & 0.0373 & 0.0129 & $9.5 \%$ & $1.04[1.01,1.06]$ \\
\hline Olthof 2017 & 0.9361 & 0.3096 & $2.5 \%$ & $2.55[1.39,4.68]$ \\
\hline Postlewait 2016 & 0.3075 & 0.1672 & $5.2 \%$ & $1.36[0.98,1.89]$ \\
\hline Ribeiro 2012 & 0.0484 & 0.1239 & $6.6 \%$ & $1.05[0.82,1.34]$ \\
\hline Shiba 2013 & 0.6206 & 0.524 & $1.1 \%$ & $1.86[0.67,5.19]$ \\
\hline Zakaria 2007 & 0.4055 & 0.1139 & $6.9 \%$ & $1.50[1.20,1.88]$ \\
\hline Zimmitti 2016 & 0.1484 & 0.2091 & $4.2 \%$ & $1.16[0.77,1.75]$ \\
\hline Total (9570 CI) & & & $100.0 \%$ & $1.24[1.11,1.38$ \\
\hline \multicolumn{5}{|c|}{$\begin{array}{l}\text { Heterogeneity: } \text { Tau }^{2}=0.03 ; \mathrm{Chi}^{2}=69.04, \mathrm{df}=20(P<0.00001) ;\left.\right|^{2}=71 \% \\
\text { Test for overall effect: } Z=3.73(P=0.0002)\end{array}$} \\
\hline
\end{tabular}

Risk Ratio IV. Random, $95 \% \mathrm{Cl}$

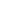

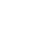

]

]

]


Table 3: Meta-regression analysis between pooled relative risk and co-variates of overall survival.

\begin{tabular}{|l|c|c|c|c|}
\hline \multicolumn{1}{|c|}{ Co-variates } & Coefficient & 95\% CI & Std. Err. & $P$-value \\
\hline Year of publication & 0.2546 & $0.1310,0.3783$ & 0.0631 & $<0.001$ \\
\hline Sample size & 0.1655 & $0.0296,0.3015$ & 0.0694 & 0.017 \\
\hline Country of patients & 0.1160 & $0.0953,0.1367$ & 0.0106 & $<0.001$ \\
\hline
\end{tabular}

Abbreviations: $\mathrm{CI}=$ confidence interval

The 5-year OS and DFS of transfused patients ranged from $21.5 \%$ to $62.7 \%$ and $14.7 \%$ to $42 \%$ respectively $v s .24$ $66.2 \%$ and $19.5-55 \%$ in nontransfused patients. Pooled analysis showed that transfusion correlated with poor OS $(P=0.0002)$ (Figure 3$)$ and DFS $(P<0.001)$ (Figure 4$)$. The summary of risk ratio (RR) estimates by multivariate analysis was 1.37 (95\% confidence intervals [CI] $=1.12$ $1.68 ; P=0.002)$ in 11 studies $[2,6-8,12,17-19,24-26]$ for OS, and $1.40(95 \% \mathrm{CI}=1.25-1.58 ; P<0.001)$ for DFS in six studies $[6,8,11,17,19,20]$. In sensitivity analysis, removing of any single study from the analysis did not affect the overall results regarding the negative association between transfusion and long-term survival (data not shown).

There was significant heterogeneity between studies $\left(\mathrm{I}^{2}=71 \%\right)$ regarding the impact of PBT on OS. In meta-regression analysis, year of publication, sample size, and country of patients were significant sources of heterogeneity (Table 3).

\section{Publication bias}

A funnel plot reveals asymmetry for the effect of PBT on OS indicating the presence of publication bias (Figure 5).

\section{DISCUSSION}

While blood transfusion is important in maintaining

\begin{tabular}{|c|c|c|c|c|c|c|c|c|}
\hline Studv or Subgroup & log[Risk Ratio] & SE & Weight & $\begin{array}{c}\text { Risk Ratio } \\
\text { IV, Random, } 95 \% \mathrm{Cl}\end{array}$ & & $\begin{array}{r}\text { Risk } \\
\text { IV, Rando }\end{array}$ & $\begin{array}{l}\text { Ratio } \\
\mathrm{m}, 95 \% \mathrm{Cl}\end{array}$ & \\
\hline Cannon 2013 & 0.3232 & 0.3452 & $2.9 \%$ & $1.38[0.70,2.72]$ & & & 10 & \\
\hline Farid 2010 & 0.2882 & 0.1277 & $15.9 \%$ & $1.33[1.04,1.71]$ & & & - & \\
\hline Giuliante 2010 & 0.6828 & 0.2311 & $6.1 \%$ & $1.98[1.26,3.11]$ & & & $\longrightarrow$ & \\
\hline Hallet 2015 & 0.5365 & 0.1478 & $12.8 \%$ & $1.71[1.28,2.28]$ & & & $\rightarrow$ & \\
\hline Ito 2008 & 0.4824 & 0.3186 & $3.4 \%$ & $1.62[0.87,3.02]$ & & & & \\
\hline Jiang 2013 & 0.3365 & 0.3383 & $3.0 \%$ & $1.40[0.72,2.72]$ & & & & \\
\hline Olthof 2017 & 0.2624 & 0.2351 & $5.9 \%$ & $1.30[0.82,2.06]$ & & & $\rightarrow$ & \\
\hline Ribeiro 2012 & 0.4033 & 0.2343 & $5.9 \%$ & $1.50[0.95,2.37]$ & & & 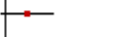 & \\
\hline Schiergens 2015 & 0.5008 & 0.2306 & $6.1 \%$ & $1.65[1.05,2.59]$ & & & $\longrightarrow$ & \\
\hline Zakaria 2007 & 0.2624 & 0.0852 & $26.4 \%$ & $1.30[1.10,1.54]$ & & & - & \\
\hline Zimmitti 2016 & -0.0619 & 0.1578 & $11.6 \%$ & $0.94[0.69,1.28]$ & & & & \\
\hline Total $(95 \% \mathrm{Cl})$ & & & $100.0 \%$ & $1.38[1.23,1.56]$ & & & 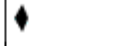 & \\
\hline \multicolumn{5}{|c|}{$\begin{array}{l}\text { Heterogeneity: } \operatorname{Tau}^{2}=0.01 ; \mathrm{Chi}^{2}=12.03, \mathrm{df}=10(\mathrm{P}=0.28) ; \mathrm{I}^{2}=17 \% \\
\text { Test for overall effect: } Z=5.37(\mathrm{P}=0.00001)\end{array}$} & 0.0 & $\begin{array}{l}0.1 \\
\text { Transfusion }\end{array}$ & 1 No trans & $\begin{array}{l}10 \\
\text { usion }\end{array}$ \\
\hline
\end{tabular}

Figure 4: Results of the meta-analysis on disease-free survival.

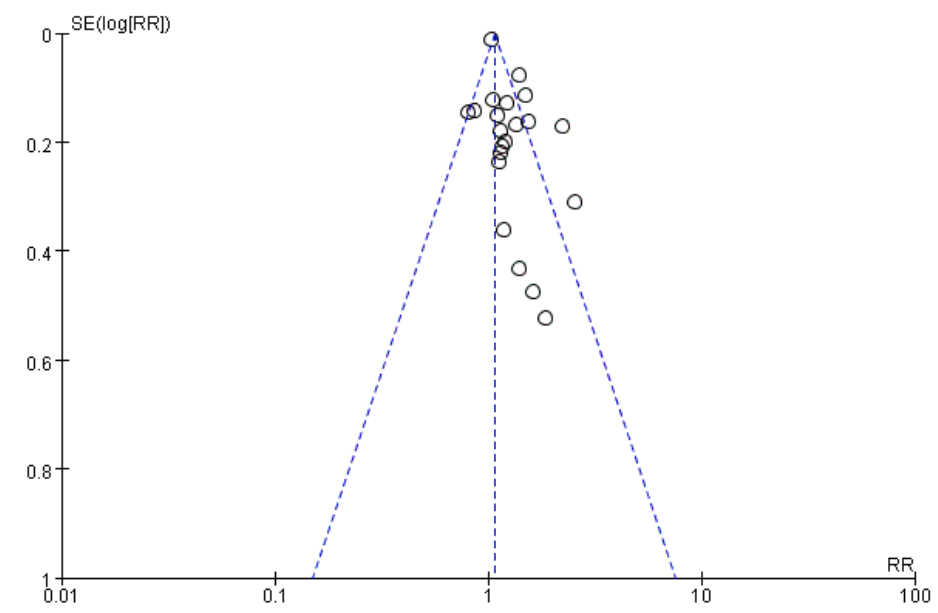

Figure 5: Funnel plot for the results from overall survival. 
hemodynamic stability and end organ perfusion during complex surgeries, it still carries significant risks, including incompatibility, transmission of infectious agents, coagulopathy, allergic reactions, and tumorpromoting action [30]. Since Burrows and Tartter first reported that $\mathrm{PBT}$ may worsen the postoperative survival of patients with bowel cancer in 1982 [31], a large number of authors have investigated the impact of PBT on clinical outcomes in patients with cancer subjected to surgery. In the field of hepatopancreaticobiliary oncological surgery, a meta-analysis of 23 studies reported that patients receiving PBT had significantly lower 5-year survival after curative-intent pancreatic surgery (OR, 2.43, 95\% $\mathrm{CI}=1.90-3.10$ ) [32]. Another meta-analysis of 22 studies noted that hepatocellular carcinoma patients receiving PBT had an increased risk of all-cause death at 3 and 5 years after surgery (respectively: $\mathrm{OR}=1.92,95 \% \mathrm{CI}, 1.61$ 2.29; $\mathrm{OR}=1.60,95 \% \mathrm{CI}, 1.47-1.73$ ) compared with those without PBT [33]. In contrast, the evidence is less clear in CLM surgery. To the best of our knowledge, this is the first meta-analysis that selectively focused on surgical CLM populations. The result clearly indicates that PBT compromised long-term survival dramatically.

Beyond its deleterious effect on long-term outcomes after surgery, PBT is also associated with adverse perioperative sequelae as measured by overall morbidity, major complications, mortality, and length of stay in the current study. More specifically, more occurrences of postoperative infection or liver failure were observed in patients receiving $\mathrm{PBT}[6,11]$.In a recent review of 712 consecutive elective hepatectomy (all diseases), Hallet et al. [34] found that PBT was associated with an increased rate of major complications and a longer length of hospital stay. The observations from non-hepatic surgery also demonstrated similar results $[35,36]$.

An important issue is whether the association between PBT and the outcome variables analyzed represents a causative effect or whether there are unmanageable confounders acting inwardly. It can be presumed certain that the transfused patients may represent a compromised and vulnerable cohort, and poor outcomes may be attributed to other factors associated with PBT unless otherwise further confirmed by a multivariate model [20]. Indeed, the results of our pooled data of multivariate RR are similar to the findings from overall analysis regarding long-term survival. Although we were unable to pool multivariate RR for perioperative outcomes due to insufficient data, in one included study, PBT was identified at multivariate analysis as a significant predictor of overall morbidity, major complications and mortality after other variables were adjusted [5]. Therefore, there are risks linked to poor postoperative outcomes inherently associated with transfusion per se rather than a confounder.

The mechanism underlying the detrimental effect of PBT on postoperative outcomes after oncologic surgery remains to be elucidated. One possible reason is the immunosuppressive effect of transfusion. The observed alterations include suppression of cytotoxic cells and monocyte activity, release of immunosuppressive prostaglandins, inhibition of interleukin-2 production, and increase in suppressor T-cell activity [30].

This meta-analysis has several potential limitations. First, all included studies are observational studies that provided a low level of evidence. Studies may have differed with regard to the baseline characteristics of the patients, tumor size or disease stage, operative procedures, the amount of blood loss, adjuvant treatment, and the follow-up duration. The results therefore are susceptible to heterogeneity. Second, the timing or amount of transfusion received was not taken into account because most of these published studies lacked relevant information. Finally, the review was restricted to articles published in English. This selection could favor the positive studies, as positive results tend to be published in English-language journals, while negative studies tend to be reported in native languages. There is therefore a publication bias.

In conclusion, PBT has a detrimental impact on clinical outcomes in patients undergoing CLM resection. Both surgeons and anesthesiologists need to manage perioperative care from various aspects to minimize the use of transfusion.

\section{MATERIALS AND METHODS}

This study was done in accordance with the recommendations of the preferred reporting items for systematic reviews and meta-analyses (PRISMA) [28].

\section{Study selection and criteria for inclusion}

A systematic search of PubMed, Science Citation Index, and Embase databases was performed to identify relevant articles from the time of inception to March 2017 using the following key words: colorectal liver metastases, liver resection, and transfusion. Manual search of reference lists of all retrieved articles was carried out to identify additional studies.

Original publications in the English language examining the impact of PBT on the on short- and longterm outcomes following CLM resection were eligible. Letters, reviews, abstracts, editorials, expert opinions, non-English language papers, duplicated studies, and animal studies were excluded.

\section{Data extraction and outcomes of interest}

Two reviewers (XL and YL, respectively) independently extracted relevant data regarding the characteristics of study and outcomes of interest from each selected article by using standardized data extraction 
forms. Discrepancies were resolved through discussion and consensus.

The outcomes of interest were clinicopathologic characteristics, postoperative morbidity and mortality, OS and DFS.

\section{Assessment of methodological quality}

The methodological quality of included studies was assessed by using the Newcastle-Ottawa Scale. Scores are assigned for patient selection, comparability of the study groups, and outcome assessment [29].

\section{Statistical analysis}

The effect measures estimated were odds ratios (OR) 95\% CI for dichotomous variables and weighted mean difference (WMD) with a 95\% CI for continuous data. The RR with $95 \%$ CI was used to assess the prognostic value of transfusion. The $\mathrm{I}^{2}$ statistic was calculated to assess the heterogeneity in results across studies with values $>50 \%$ representing substantial heterogeneity. A funnel plot based on the OS was used to detect the possibility of publication bias. Sensitivity analyses were carried out to investigate the impact of individual study on the overall outcome of the meta-analysis. Meta-regression was performed with the following co-variates: sample size, year of publication, and country of patients. Statistical analyses were performed with Review Manager version 5.3 (The Cochrane Collaboration, Software Update, Oxford) and Stata $^{\mathrm{TM}}$ version 8.0 (Stata Corporation, College Station, Texas, USA). Values of $P<0.05$ were considered statistically significant.

\section{Abbreviations}

CLM: colorectal liver metastasis; OS: overall survival; PBT: perioperative blood transfusion; OR: odds ratios; CI: confidence intervals; WMD: weighted mean difference; RR: risk ratio.

\section{Authors' contributions}

XL and YL contributed to conception and design of the study. WQ and DL contributed to the data acquisition, analysis and interpretation of the data. XL and YL contributed to writing and editing the manuscript. All authors commented on drafts of the paper and have approved the final draft of the manuscript.

\section{CONFLICTS OF INTEREST}

The authors indicated no financial relationships.

\section{REFERENCES}

1. Mohammad WM, Balaa FK. Surgical management of colorectal liver metastases. Clin Colon Rectal Surg. 2009; 22: 225-32. doi: 10.1055/s-0029-1242462.

2. Ohlsson B, Stenram U, Tranberg KG. Resection of colorectal liver metastases: 25-year experience. World J Surg. 1998; 22: 268-76; discussion 76-7.

3. Ambiru S, Miyazaki M, Isono T, Ito H, Nakagawa K, Shimizu H, Kusashio K, Furuya S, Nakajima N. Hepatic resection for colorectal metastases: analysis of prognostic factors. Dis Colon Rectum. 1999; 42: 632-9.

4. Ercolani G, Grazi GL, Ravaioli M, Cescon M, Gardini A, Varotti G, Del Gaudio M, Nardo B, Cavallari A. Liver resection for multiple colorectal metastases: influence of parenchymal involvement and total tumor volume, vs number or location, on long-term survival. Arch Surg. 2002; 137: 1187-92.

5. Kooby DA, Stockman J, Ben-Porat L, Gonen M, Jarnagin WR, Dematteo RP, Tuorto S, Wuest D, Blumgart LH, Fong Y. Influence of transfusions on perioperative and long-term outcome in patients following hepatic resection for colorectal metastases. Ann Surg. 2003; 237: 860-9; discussion 9-70. doi: 10.1097/01.SLA.0000072371.95588. DA.

6. Laurent C, Sa Cunha A, Couderc P, Rullier E, Saric J. Influence of postoperative morbidity on long-term survival following liver resection for colorectal metastases. Br J Surg. 2003; 90: 1131-6. doi: 10.1002/bjs.4202.

7. Zakaria S, Donohue JH, Que FG, Farnell MB, Schleck CD, Ilstrup DM, Nagorney DM. Hepatic resection for colorectal metastases: value for risk scoring systems? Ann Surg. 2007; 246: 183-91. doi: 10.1097/SLA.0b013e3180603039.

8. Arru M, Aldrighetti L, Castoldi R, Di Palo S, Orsenigo E, Stella M, Pulitano C, Gavazzi F, Ferla G, Di Carlo V, Staudacher C. Analysis of prognostic factors influencing long-term survival after hepatic resection for metastatic colorectal cancer. World J Surg. 2008; 32: 93-103. doi: 10.1007/s00268-007-9285-y.

9. Ito H, Are C, Gonen M, D'Angelica M, Dematteo RP, Kemeny NE, Fong Y, Blumgart LH, Jarnagin WR. Effect of postoperative morbidity on long-term survival after hepatic resection for metastatic colorectal cancer. Ann Surg. 2008; 247: 994-1002. doi: 10.1097/SLA.0b013e31816c405f.

10. Marin Hernandez C, Robles Campos R, Perez Flores D, Lopez Conesa A, Parrilla Paricio P. [Prognostic factors after resection of colorectal cancer liver metastases]. [Article in Spanish]. Cir Esp. 2009; 85: 32-9. doi: 10.1016/S0009739X(09)70084-3.

11. Farid SG, Aldouri A, Morris-Stiff G, Khan AZ, Toogood GJ, Lodge JP, Prasad KR. Correlation between postoperative infective complications and long-term outcomes after hepatic resection for colorectal liver metastasis. Ann Surg. 2010; 251: 91-100. doi: 10.1097/ SLA.0b013e3181bfda3c. 
12. Giuliante F, Ardito F, Pulitano C, Vellone M, Giovannini I, Aldrighetti L, Ferla G, Nuzzo G. Does hepatic pedicle clamping affect disease-free survival following liver resection for colorectal metastases? Ann Surg. 2010; 252: 1020-6. doi: 10.1097/SLA.0b013e3181f66918.

13. Gruttadauria S, Saint Georges Chaumet M, Pagano D, Marsh JW, Bartoccelli C, Cintorino D, Arcadipane A, Vizzini G, Spada M, Gridelli B. Impact of blood transfusion on early outcome of liver resection for colorectal hepatic metastases. J Surg Oncol. 2011; 103: 140-7. doi: 10.1002/ jso. 21796 .

14. Kaibori M, Iwamoto Y, Ishizaki M, Matsui K, Yoshioka K, Asano H, Kwon AH. Predictors and outcome of early recurrence after resection of hepatic metastases from colorectal cancer. Langenbecks Arch Surg. 2012; 397: 37381. doi: 10.1007/s00423-011-0861-0.

15. Ribeiro HS, Stevanato-Filho PR, Costa Jr WL, Diniz AL, Herman P, Coimbra FJ. Prognostic factors for survival in patients with colorectal liver metastases: experience of a single brazilian cancer center. Arq Gastroenterol. 2012; 49: 266-72.

16. Cannon RM, Brown RE, St Hill CR, Dunki-Jacobs E, Martin RC 2nd, McMasters KM, Scoggins CR. Negative effects of transfused blood components after hepatectomy for metastatic colorectal cancer. Am Surg. 2013; 79: 35-9.

17. Jiang W, Fang YJ, Wu XJ, Wang FL, Lu ZH, Zhang RX, Ding PR, Fan WH, Pan ZZ, De-Sen W. Intraoperative blood loss independently predicts survival and recurrence after resection of colorectal cancer liver metastasis. PLoS One. 2013; 8: e76125. doi: 10.1371/journal.pone.0076125.

18. Shiba H, Ishida Y, Haruki K, Furukawa K, Fujiwara Y, Iwase R, Ohkuma M, Ogawa M, Misawa T, Yanaga K. Negative impact of fresh-frozen plasma transfusion on prognosis after hepatic resection for liver metastases from colorectal cancer. Anticancer Res. 2013; 33: 2723-8.

19. Hallet J, Tsang M, Cheng ES, Habashi R, Kulyk I, Hanna SS, Coburn NG, Lin Y, Law CH, Karanicolas PJ. The Impact of Perioperative Red Blood Cell Transfusions on Long-Term Outcomes after Hepatectomy for Colorectal Liver Metastases. Ann Surg Oncol. 2015; 22: 4038-45. doi: 10.1245/s10434-015-4477-4.

20. Schiergens TS, Rentsch M, Kasparek MS, Frenes K, Jauch KW, Thasler WE. Impact of perioperative allogeneic red blood cell transfusion on recurrence and overall survival after resection of colorectal liver metastases. Dis Colon Rectum. 2015; 58: 74-82. doi: 10.1097/ DCR.0000000000000233.

21. Postlewait LM, Squires MH 3rd, Kooby DA, Weber SM, Scoggins CR, Cardona K, Cho CS, Martin RC, Winslow ER, Maithel SK. The relationship of blood transfusion with peri-operative and long-term outcomes after major hepatectomy for metastatic colorectal cancer: a multiinstitutional study of 456 patients. HPB (Oxford). 2016; 18: 192-9. doi: 10.1016/j.hpb.2015.08.003.
22. Zimmitti G, Soliz J, Aloia TA, Gottumukkala V, Cata JP, Tzeng CW, Vauthey JN. Positive Impact of Epidural Analgesia on Oncologic Outcomes in Patients Undergoing Resection of Colorectal Liver Metastases. Ann Surg Oncol. 2016; 23: 1003-11. doi: 10.1245/s10434-015-4933-1.

23. Kulik U, Schrem H, Bektas H, Klempnauer J, Lehner F. Prognostic relevance of hematological profile before resection for colorectal liver metastases. J Surg Res. 2016; 206: 498-506. doi: 10.1016/j.jss.2016.08.012.

24. Margonis GA, Kim Y, Samaha M, Buettner S, Sasaki K, Gani F, Amini N, Pawlik TM. Blood loss and outcomes after resection of colorectal liver metastases. J Surg Res. 2016; 202: 473-80. doi: 10.1016/j.jss.2016.01.020.

25. Bell R, Pandanaboyana S, Nisar S, Upasani V, Toogood G, Lodge JP, Prasad KR. The Impact of Advancing Age on Recurrence and Survival Following Major Hepatectomy for Colorectal Liver Metastases. J Gastrointest Surg. 2017; 21 : 266-74. doi: 10.1007/s11605-016-3296-7.

26. Olthof PB, Huiskens J, Schulte NR, Wicherts DA, Besselink MG, Busch OR, Tanis PJ, van Gulik TM. Hepatic vascular inflow occlusion is associated with reduced disease free survival following resection of colorectal liver metastases. Eur J Surg Oncol. 2017; 43: 100-6. doi: 10.1016/j. ejso.2016.09.003.

27. Dindo D, Demartines N, Clavien PA. Classification of surgical complications: a new proposal with evaluation in a cohort of 6336 patients and results of a survey. Ann Surg. 2004; 240: 205-13.

28. Moher D, Liberati A, Tetzlaff J, Altman DG, PRISMA Group. Preferred reporting items for systematic reviews and meta-analyses: the PRISMA statement. J Clin Epidemiol. 2009; 62: 1006-12. doi: 10.1016/j.jclinepi.2009.06.005.

29. Athanasiou T, Al-Ruzzeh S, Kumar P, Crossman MC, Amrani M, Pepper JR, Del Stanbridge R, Casula R, Glenville B. Off-pump myocardial revascularization is associated with less incidence of stroke in elderly patients. Ann Thorac Surg. 2004; 77: 745-53. doi: 10.1016/j. athoracsur.2003.07.002.

30. Cata JP, Wang H, Gottumukkala V, Reuben J, Sessler DI. Inflammatory response, immunosuppression, and cancer recurrence after perioperative blood transfusions. Br J Anaesth. 2013; 110: 690-701. doi: 10.1093/bja/aet068.

31. Burrows L, Tartter P. Effect of blood transfusions on colonic malignancy recurrent rate. Lancet. 1982; 2: 662.

32. Mavros MN, Xu L, Maqsood H, Gani F, Ejaz A, Spolverato G, Al-Refaie WB, Frank SM, Pawlik TM. Perioperative Blood Transfusion and the Prognosis of Pancreatic Cancer Surgery: Systematic Review and Meta-analysis. Ann Surg Oncol. 2015; 22: 4382-91. doi: 10.1245/s10434-015-48236.

33. Liu L, Wang Z, Jiang S, Shao B, Liu J, Zhang S, Zhou Y, Zhou Y, Zhang Y. Perioperative allogenenic blood transfusion is associated with worse clinical outcomes for hepatocellular carcinoma: a meta-analysis. PLoS One. 
2013; 8: e64261. doi: 10.1371/journal.pone.0064261.

34. Hallet J, Kulyk I, Cheng ES, Truong J, Hanna SS, Law CH, Coburn NG, Tarshis J, Lin Y, Karanicolas PJ. The impact of red blood cell transfusions on perioperative outcomes in the contemporary era of liver resection. Surgery. 2016; 159: 1591-9. doi: 10.1016/j.surg.2015.12.015.

35. O'Keeffe SD, Davenport DL, Minion DJ, Sorial EE, Endean ED, Xenos ES. Blood transfusion is associated with increased morbidity and mortality after lower extremity revascularization. J Vasc Surg. 2010; 51: 616-21, 21 e1-3. doi: 10.1016/j.jvs.2009.10.045.
36. Thomas P, Michelet P, Barlesi F, Thirion X, Doddoli C, Giudicelli R, Fuentes P. Impact of blood transfusions on outcome after pneumonectomy for thoracic malignancies. Eur Respir J. 2007; 29: 565-70. doi: 10.1183/09031936.00059506. 